\title{
ARID2 wt Allele
}

National Cancer Institute

\section{Source}

National Cancer Institute. ARID2 wt Allele. NCI Thesaurus. Code C101089.

Human ARID2 wild-type allele is located in the vicinity of $12 q 12$ and is approximately 178 $\mathrm{kb}$ in length. This allele, which encodes AT-rich interactive domain-containing protein 2, plays a role in both the modulation of chromatin remodeling and transcriptional regulation. 